\title{
Respon Imun Pada Penderita Asma Selama Kehamilan
}

\author{
Immune Response In Asthma Patients During Pregnancy
}

\author{
Wiwik Agustina \\ Program Studi Profesi Ners, STIKes Maharani Malang \\ Email: ns_wi2k@yahoo.com
}

\begin{abstract}
The immune system of a woman while pregnant it would be more sensitive than usual. Therefore, pregnant women are particularly vulnerable to some diseases, particularly influenza. A new study suggests that women who often experience flu during pregnancy, would be at risk of having children with asthma. In addition, asthma and allergies can also be inheritable. If both parents have allergies, the child has an allergy risk 75 percent. If only one parent with allergies, or if a near of kin has an allergy, the child will have a 30 to 40 percent risk of experiencing various types of allergies. However, if the parents do not have allergies at all, the risk of allergies in children only 10 to 15 percent. This scientific work aimed to determine the immune response in pregnant women with a asthma. This scientific work methods using literature study. Effect of pregnancy on the incidence of asthma attacks in each patient are not the same, even attacks are not common in a first pregnancy and subsequent pregnancies. Usually the attack will arise from the age of 24 weeks to 36 weeks, and will be reduced by the end of pregnancy. Effect of asthma in mother and the fetus is very dependent on the frequency and severity of asthma attacks, because of the mother and the fetus will experience hypoxia. Hypoxia if not addressed would have a detrimental effect on the fetus, such as miscarriage, premature delivery, and fetal weight were not in accordance with gestational age. It is expected the public to give more attention and be aware in patients with asthma, especially in during pregnancy.
\end{abstract}

Keywords : immune system, pregnant women , asthma

\section{Pendahuluan}

Sistem imun mengacu pada kemampuan tubuh menahan atau mengeliminasi benda asing atau sel abnormal yang potensial berbahaya. Aktifitas-aktifitas berikut berkaitan dengan sistem pertahanan imun, yang berperan penting dalam mengenali dan menghancurkan atau menetralisasi bendabenda di dalam tubuh yang dianggap asing oleh tubuh normal. Peranan utama dari sistem imun adalah untuk melindungi tubuh dari invasi organisme asing dan produk toksin mereka. Hal ini membutuhkan kemampuan untuk mendiskriminasikan antara selama 9 bulan, tidak terancam oleh sistem imun wanita. Singkatnya, adaptasi imun harus terjadi pada self antigen dan nonself antigen, sehingga sistem imun dapat merusak organisme yang menyerang dan bukan jaringan normal. Dalam kehamilan, janin yang merupakan antigen asing tumbuh di dalam rahim wanitanya kehamilan yang sangat penting untuk kelangsungan hidup janin sambil mempertahankan kemampuan wanita untuk melawan infeksi (Reece A, 2007).

Sistem imun seorang wanita saat hamil memang akan lebih sensitif dari biasanya. Oleh karena itu, wanita hamil sangat rentan terhadap beberapa penyakit, terutama flu. Sebuah studi baru menunjukkan, wanita yang sering mengalami flu selama kehamilan, akan lebih berisiko melahirkan anak dengan riwayat asma. Penelitian yang diterbitkan dalam jurnal Annals of Allergy, Asthma and Immunology tersebut mengatakan bahwa, semakin sering seorang wanita hamil mengalami flu, masuk angin, atau infeksi virus, semakin tinggi risiko bayi 
yang akan dilahirkannya mengalami asma pada masa kanak-kanaknya kelak. Dilansir sumber dari Daily Mail, Dr Mitch Grayson, Ahli Alergi dari American College of Allergy, Asthma and Immunology mengatakan, anak-anak yang berisiko alergi tersebut umumnya memiliki beberapa faktor pemicu, seperti debu rumah dan bulu hewan peliharaan. Umumnya, kasus alergi ini akan berkembang saat anak memasuki usia 5 tahun. Sebanyak 513 wanita hamil dan 526 anak-anak di Jerman dilibatkan dalam penelitian ini. Mereka diteliti melalui kuisioner yang dilakukan secara berkala, yaitu pada saat kehamilan, ketika anak mereka berusia 3 bulan, 12 bulan, lalu setiap tahun hingga berusia 5 tahun. Hasilnya, sebanyak 61 persen anak yang asma terbukti memiliki orangtua yang mengalami demam flu atau dermatitis atopik saat kehamilannya. Selain itu, asma dan alergi juga bisa menurun. Jika kedua orang tua memiliki alergi, maka anak berisiko 75 persen mengalami alergi. Jika hanya salah satu orang tua yang alergi, atau jika kerabat dekat memiliki alergi, anak akan memiliki risiko 30 sampai 40 persen mengalami berbagai jenis alergi. Namun, jika orang tua tidak memiliki alergi sama sekali, risiko terjadinya alergi pada anak hanya 10 sampai 15 persen saja (ACAAI, 2002).

Asma bronkiale merupakan penyakit yang ditandai dengan meningkatnya kepekaan saluran trakeobronkial terhadap berbagai rangsangan. Pada serangan asma terjadi bronkospasme, pembengkakan mukosa dan peningkatan sekresi saluran nafas, yang dapat hilang secara spontan atau dengan pengobatan. Gejala klinik yang klasik berupa batuk, sesak nafas, dan mengi (wheezing), serta bisa juga disertai nyeri dada. Serangan asma umumnya berlangsung singkat dan akan berakhir dalam beberapa menit sampai jam, dan setelah itu penderita kelihatan sembuh secara klinis. Pada sebagian kecil kasus terjadi keadaan yang berat, yang mana penderita tidak memberikan respon terhadap terapi (obat agonis beta dan teofilin), hal ini disebut status asmatikus (Wray, 2003).

Pengaruh asma pada wanita dan janin sangat bergantung dari frekuensi dan beratnya serangan asma, karena wanita dan janin akan mengalami hipoksia. Keadaan hipoksia jika tidak segera diatasi tentu akan memberikan pengaruh buruk pada janin, berupa abortus, persalinan prematur, dan berat janin yang tidak sesuai dengan umur kehamilan (Subijanto, 2008). Berdasarkan uraian tersebut diatas, maka peneliti tertarik untuk melakukan studi literatur mengenai respon imun pada penderita asma saat proses kehamilan.

\section{Metode Penulisan}

Metode penulisan Karya Ilmiah dengan judul " respon imun pada penderita asma saat proses kehamilan" menggunakan studi literatur dari berbagai sumber.

\section{Pembahasan}

\section{Sistem Imun Pada Wanita Hamil Sistem Pernafasan Selama Kehamilan}

Selama kehamilan, terjadi perubahan fisiologi sistem pernafasan yang disebabkan oleh perubahan hormonal dan faktor mekanik. Perubahan-perubahan ini diperlukan untuk mencukupi peningkatan kebutuhan metabolik dan sirkulasi untuk pertumbuhan janin, plasenta dan uterus. Selama kehamilan kapasitas vital pernapasan tetap sama dengan kapasitas sebelum hamil yaitu 3200 cc, akan tetapi terjadi peningkatan volume tidal dari $450 \mathrm{cc}$ menjadi $600 \mathrm{cc}$, yang menyebabkan terjadinya peningkatan ventilasi permenit selama kehamilan antara 19-50\%. Peningkatan volume tidal ini diduga disebabkan oleh efek progesteron terhadap resistensi saluran nafas dan dengan meningkatkan sensitifitas pusat pernapasan terhadap karbondioksida. Dari faktor mekanis, terjadinya peningkatan diafragma terutama setelah pertengahan kedua kehamilan akibat membesarnya janin, menyebabkan turunnya kapasitas residu fungsional, yang merupakan volume udara yang tidak digunakan dalam paru, sebesar $20 \%$. Selama kehamilan normal terjadi penurunan resistensi saluran napas sebesar 50\% (Nelson and Piercy, 2001). 
Perubahan-perubahan ini menyebabkan terjadinya perubahan pada kimia dan gas darah. Karena meningkatnya ventilasi maka terjadi penurunan $\mathrm{pCO} 2$ menjadi $30 \mathrm{mmHg}$, sedangkan pO2 tetap berkisar dari 90-106 $\mathrm{mmHg}$, sebagai penurunan $\mathrm{pCO} 2$ akan terjadi mekanisme sekunder ginjal untuk mengurangi plasma bikarbonat menjadi $18-22 \mathrm{mEq} / \mathrm{L}$, sehingga $\mathrm{pH}$ darah tidak mengalami perubahan. Secara anatomi terjadi peningkatan sudut subkostal dari 68,5-103,5 selama kehamilan. Perubahan fisik ini disebabkan karena elevasi diafragma sekitar 4 $\mathrm{cm}$ dan peningkatan diameter transversal dada maksimal sebesar $2 \mathrm{~cm}$. Adanya perubahanperubahan ini menyebabkan perubahan pola pernapasan dari pernapasan abdominal menjadi torakal yang juga memberikan pengaruh untuk memenuhi peningkatan konsumsi oksigen maternal selama kehamilan. Laju basal metabolisme meningkat selama kehamilan seperti terbukti oleh peningkatan konsumsi oksigen. Selama melahirkan, konsumsi O2 dapat meningkat 20-25\%. Bila fungsi paru terganggu karena penyakit paru, kemampuan untuk meningkatkan konsumsi oksigen terbatas dan mungkin tidak cukup untuk mendukung partus normal, sebagai konsekuensi fetal distress dapat terjadi (Nelson and Piercy, 2001).

\section{Perubahan Hormonal Selama Kehamilan}

Keadaan hormonal selama kehamilan sangat berbeda dengan keadaan tidak hamil dan mengalami perubahan selama perjalanan kehamilan. Perubahan-perubahan ini akan memberikan pengaruh terhadap fungsi paru. Progesteron tampaknya memberikan pengaruh awal dengan meningkatkan sensitifitas terhadap $\mathrm{CO} 2$, yang menyebabkan terjadinya hiperventilasi ringan, yang bisa disebut sebagai dispnea selama kehamilan. Lebih lanjut dapat dilihat adanya efek relaksasi otot polos. Pengaruh total progesteron selama kehamilan karena peningkatannya yang mencapai 50-100 kali dari keadaan tidak hamil, masih diperdebatkan dengan adanya berbagai temuan klinis yang terbuka diperdebatkan (Hertantiyo, 2013).

Selama kehamilan kadar estrogen meningkat, dan terdapat data-data yang menunjukkan bahwa peningkatan ini menyebabkan menurunnya kapasitas difusi pada jalinan kapiler karena meningkatnya jumlah sekresi asam mukopolisakarida perikapiler. Estrogen memberikan pengaruh terhadap asma selama kehamilan dengan menurunkan klirens metabolik glukokortikoid sehingga terjadi peningkatan kadar kortisol. Estrogen juga mempotensiasi relaksasi bronkial yang diinduksi oleh isoproterenol. Kadar kortisol bebas plasma meningkat selama kehamilan, demikian pula kadar total kortisol plasma. Peningkatan kadar kortisol ini seharusnya memberikan perbaikan terhadap keadaan penderita asma, akan tetapi dalam kenyataannya tidak demikian. Tampaknya beberapa wanita hamil refrakter terhadap kortisol meskipun terjadi peningkatan kadar dalam serum 2-3 kali lipat. Hal ini mungkin disebabkan terjadinya kompetisi pada reseptor glukokortikoid oleh progesteron, deoksikortikosteron dan aldosteron yang semuanya meningkat selama kehamilan (Hertantiyo, 2013).

Semua tipe prostaglandin meningkat dalam serum maternal selama kehamilan, terutama menjelang persalinan aterm. Meskipun dijumpai adanya peningkatan kadar metabolik prostalandin PGF $2 \mathrm{x}$ yang merupakan suatu bronkokonstriktor kuat, dalam serum sebesar 10\%-30\%, hal ini tidak selalu memberikan pengaruh buruk pada penderita asma selama persalinan. Pada jaringan janin ditemukan histamin dalam konsentrasi tinggi. Sebagai respon terhadap stimulus ini maka plasenta menghasilkan histaminase (diaminoksidase) dalam jumlah besar mencapai 1000 kali lipat dibandingkan wanita yang tidak hamil (Hertantiyo, 2013).

\section{Respon Imun Dalam Kehamilan}

Selama kehamilan kadar serum IgA dan IgM akan meningkat karena adanya peningkatan resiko infeksi. Respon imun wanita yang dipengaruhi oleh kehamilan, jumlah sel darah putih terutama neutrofil meningkat dan sel lebih cepat respon terhadap tantangan. HCG merangsang produksi dan respon neutrofil. Kadar estrogen dan progesteron yang tinggi menurunkan jumlah sel $\mathrm{T}$ helper dan meningkatkan jumlah sel penekan. Infeksi ragi meningkat pada kehamilan karena efek estrogen pada saluran reproduksi. Kontraksi lokal kortikosteroid di sekitar janin dan plasenta menekan aktifitas fisiologis terutama dalam respon terhadap bakteri gram. Hal ini berarti wanita mengalami penurunan kemampuan respon 
terhadap infeksi negative bakteri gram pada saluran reproduksi misalnya infeksi gonokokus dan E.coli (Baratawidjaja, 2010).

Sel NK (Natural Killer) dan sitokinin

Aktifitas sel NK di sekitar uterus tertekan oleh peningkatan lokal prostaglandin $\mathrm{E}_{2 .}$. Penekanan sel NK penting untuk penolakan janin, namun wanita resistensi terhadap pathogen intrasel misalnya toxoplasma dan listeria. Prororsi relatif sitokinin menurun pada kehamilan. Konseptus mengeluarkan sitokinin yang berpengaruh pada jaringan secara lokal mendorong pertumbuhan trofoblas dan kelansungan hidup janin. Sekresi lokal sitokinin penting untuk melindungi janin tanpa mengganggu fungsi imun wanita (Baratawidjaja, 2010).

\section{Antibodi dan limfosit B}

Kadar sebagian besar antibodi tidak menurun selama kehamilan tapi konsentrasi IgG mungkin turun yang disebabkan oleh hemodilusi, peningkatan pengeluaran melalui urin. Atau penyaluran IgG melalui plasenta pada trimester tiga dan hal ini dapat menigkatkan risiko infeksi. Sekresi sitokinin oleh janin menurunkan imunitas selular dan meningkatkan respon humoral. Peningkatan responsivitas limfosit B untuk mengkompensasi penurunan aktifitas limfosit $\mathrm{T}$, limfosit $\mathrm{B}$ juga menghasilkan antibodi penghambat yang melindungi janin dari serangan limfosit $\mathrm{T}$ wanita (Baratawidjaja, 2010).

\section{Limfosit T}

Selama kehamilan fungsi sel $\mathrm{T}$ tertekan terutama pada trimester 1 dalam sirkulasi lebih rendah dan kemampuan berproliferasi dan membunuh sel asing juga menurun. Rasio sel penolong dan penekan berubah akibat perubahan hormonal. Karena limfosit $\mathrm{T}$ berespon terhadap infeksi virus, maka wanita hamil dapat mengalami peningkatan risiko terjangkit infeksi virus (Baratawidjaja, 2010).

\section{Sel-Sel Imun Di Uterus}

Uterus sebagai organ tempat kehamilan akan berlangsung, tentu akan memiliki peranan penting dalam proses penerimaan embrio. Lapisan endometrium uterus dapat dianggap sebagai jaringan limfoid tersier setelah jaringan limfoid primer pada sumsum tulang dan timus serta jaringan limfoid sekunder. Pada kelenjar getah bening, limfa dan Gut Associated lympoid Tissue (GALT). Hal ini disebabkan leukosit ditemukan jumlahnya cukup banyak baik pada daerah stroma maupun epitell dari lapisan endometrium. Sejumlah leukosit didapatkan baik secara tersebar maupun berkelompok bersebelahan dengan kelenjar endometrium pada stratum basalis, dan pola ini akan berubah siklus haid. Jumlah sel-sel leukosit pada stratum fungsional akan sangat berbeda pada setiap fase dari siklus haid. Yang paling menonjol adalah perubahan pada jumlah sel NK. Jumlah sel NK akan meningkat secara bermakna pasca ovulasi dan jumlahnya akan tetap banyak pada lipatan desidua saat usia kehamilan dini (Abbas, 2010).

Dalam kehamilan, jaringan plasenta yang akan langsung mengadakan kontak dengan sistem imun maternal, hal ini disebabkan oleh sel-sel trofoblas akan menginvasi hingga pembuluh darah maternal. Respon imun maternal yang ditimbulkan janin pada alam kehamilan dapat dipicu oleh karena adanya interaksi sel-sel janin pada plasenta dan juga pengaruh faktor sistemik maternal lainnya seperti hormon (Abbas, 2010).

\section{Penggolongan Antibodi}

1) Antibodi $\operatorname{IgG}$ (Imunoglobin $G$ )

- Bagian terbesar imunoglobin serum (75\%)

- Distrwanitasi merata pada ruang intra dan ekstravaskuler

- Dapat melalui plasenta dan memberikan kekebalan pasif alamiah terhadap bayi baru lahir.

- Berperan dalam Reaksi anafilaktik

- Berperan pada bermacam-macam reaksi imunoglobin prosipitasi pengikatan, komplemen, netralisasi toksin dan virus

- Bertahan lama

- Bekerja sebagai opsonin kuat yang menjembatani fagosit dan sel sasaran.

- Penting dalam pertahanan terhadap bakteri dan pengaktifan sistem komplemen melalui jalur klasik.

- Di produksi dalam jumlah banyak pada respon adaptif sekunder.

2) Antibodi IgM (Imunoglobin $\mathrm{M}$ )

- Molekulnya bergabung dalam kelompok 5 "entamer Ig M" sehingga cenderung menggumpalkan antigen yang menjadi sasaran fagosit dan sel NK. 
- Merupakan molekul besar sehingga tidak dapat berdifusi keluar aliran darah

- Aktivator kuat sistem komplemen

- Penting dalam respon imun terhadap bakteri

- Antibodi pertama yang di produksi tubuh dalam menghadapi antigen baru

- Tidak dapat melalui plasenta

- Lebih efisien bekerja aglutinasi, sitolisis dan sitototisik.

3) Antibodi E (Imunoglobin A)

- Suatu Beta/Gamma globulin, jumlah dari globulin serum, kadar normal

- Terdapat dalam konsentrasi fungsi dalam kolostrum air mata cairan empedu, saliva, sekret sel cerna

- Tidak dapat melewati placenta

- Meningkatkan fagositosis dan penghancuran Mikroorganisme dalam sel.

4) Antibodi E (Imunoglobin E)

- Ekornya berlekatan dengan reseptor di sel mast sehingga berperan dalam peradangan akut, respon alergi dan hipersensitivitas

- Tempat pengikatan untuk antigen di parasit yang lebih besar misal cacing

- Tidak melalui plasenta

- Sebagian besar intravaskuler

- Kadar normal dalam serum kecil, asma dan infeksi cacing.

5) Antibodi D (Imunoglobin D)

- Berperan pada reaksi

- Konsentrasi dalam serum normal

- Fungsi tidak diketahui dengan jelas

- Intravaskular

- Ditemukan pada permukaan limfosit B tali pusat.

(Abbas, 2010).

\section{Respon Imun Pada Penderita Asma}

Respon imun secara garis besar dibagi menjadi 2 jalur, yaitu TH1 dan TH2. TH1 berhubungan dengan respons terhadap virus, bakteri dan parasit intrasel, ditandai oleh pembentukan sitokin-sitokin, seperti interferon gama, tumor necrotizing factor (TNF) dan interleukin (IL) 2, yang akan mengaktifkan makrofag dan sel $\mathrm{T}$ sitotoksik (Tc). TH2 berhubungan dengan respons terhadap parasit metazoa besar dan reaksireaksi alergi, ditandai oleh pembentukan sitokin-sitokin IL 4,5 dan 10, aktivasi sel mast, pembentukan $\operatorname{IgE}$ anafilaktik dan kemotaksis eosinofil, seperti apa yang terjadi pada asma (Widura, 2002).

Sel kunci dalam kedua jalur respons imun tersebut adalah limfosit T CD4+. Apa yang menyebabkan pilihan jatuh pada TH1 atau TH2 belum jelas, mungkin antigen tertentu, sitokin atau faktor genetik tertentu yang belum diketahui. Di antara respons imun TH1 dan TH2 terdapat suatu keseimbangan, interferon gama dari TH1 menghambat $\mathrm{TH} 2$, sebaliknya, IL4 dan 10 dari TH2 menghambat TH1. Bila keseimbangan ini terganggu, karena pembentukan sitokin penghambat yang berlebihan atau sebaliknya, terjadilah penyakit-penyakit imunopatologis seperti asma atau autoimunitas (Widura, 2002).

Sitokin IL4 ada1ah regulator utama respons imun $\mathrm{TH} 2$, sehingga merupakan sasaran penting dalam pengobatan asma dan penyakit alergi lain. la tidak hanya bekerja langsung pada sel B dan menginduksi pembentukan IgE, tapi juga bekerja pada limfosit T CD4+ dan mendorongnya untuk lebih banyak berdiferensiasi ke jalur TH2. Selain itu, ia juga mengatur pembentukan IL5. IL5 sendiri tidak terlalu penting dalam respons $\mathrm{TH} 2$, namun ia dapat memicu aktivitas dan proliferasi eosinofil, kehadiran eosinofil yang aktif dan produknya di da1am saluran nafas menyebabkan inflamasi dan sekresi mukus, yang sangat berperan dalam kejangkitan asma. Penelitian saat ini banyak ditujukan kepada tipe sel yang mempresentasikan alergen kepada limfosit $\mathrm{T}$ CD4+, suatu antigen presenting cell (APC) yang bukan makrofag biasa, tapi suatu sel dendritik yang 1000 kali lebih aktif (Widura, 2002).

Berikut skema gambar respon imun pada asma :

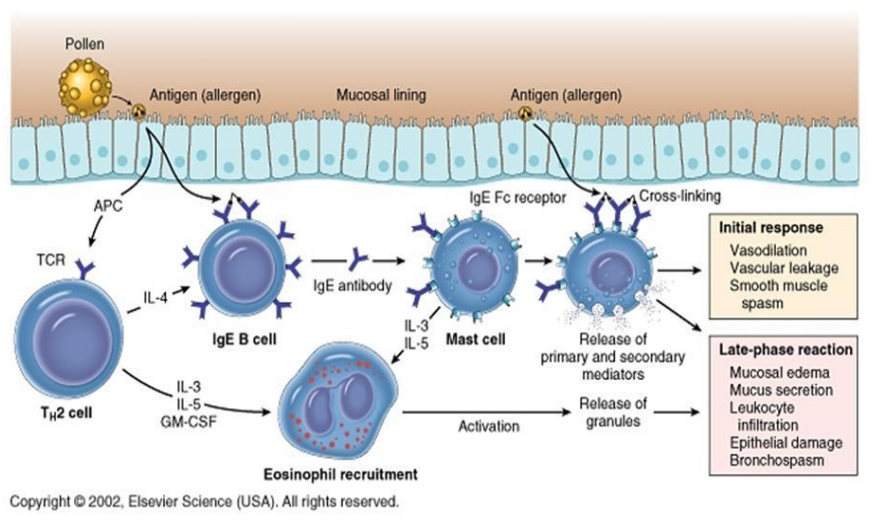

Gambar 1. Respon imun pada asma 


\section{Respon Imun Pada Wanita Hamil Dengan Asma}

Perubahan fisiologis selama kehamilan mengubah prognosis asma. Hal ini berhubungan dengan perubahan hormonal selama kehamilan. Bronkodilatasi yang dimediasi oleh progesteron serta peningkatan kadar kortisol serum bebas merupakan salah satu perubahan fisiologis kehamilan yang dapat memperbaiki gejala asma, sedangkan prostaglandin F2 dapat memperburuk gejala asma karena efek bronkokonstriksi yang ditimbulkannya (Subijanto, 2008).

Hasil penelitian menyimpulkan bahwa peningkatan kadar IgE diperkirakan akan memperburuk keadaan asma selama kehamilan, sebaliknya penderita dengan kadar IgE yang menurun akan membaik keadaannya selama kehamilan. Paparan terhadap aeroallergen pada wanita saat kehamilan dapat meningkatkan resiko sensitisasi terhadap janin sehingga pajanan alergi yang merangsang produksi IgE spesifik sudah dapat terjadi sejak bayi dalam kandungan. Hal ini dikarenakan reaksi IgE timbul segera setelah adanya pajanan dengan allergen. Reaksi ini dapat terjadi dalam hitungan menit setelah terjadi kombinasi antigen dengan antibodi yang terikat pada sel mast pada individu yang telah tersensitisasi terhadap antigen. Reaksi ini seringkali disebut sebagai alergi dan antigen yang berperan disebut dengan allergen. Allergen yang masuk ke dalam tubuh akan menimbulkan respon imun berupa produksi IgE dan penyakit alergi seperti asma, rhinitis alergi, dan dermatitis atopi. Reaksi tipe ini merupakan hipersensitifitas yang paling sering terjadi (Subowo, 2010).

Hipersensitifitas tipe I memiliki dua fase utama yaitu reaksi inisial atau segera yang ditandai dengan vasodilatasi, kebocoran vascular, tergantung pada lokasi, spasme otot polos atau sekresi grandular. Perubahan tersebut terjadi dalam 5 sampai 30 menit sesudah eksposure dan menghilang dalam 60 menit. Selanjutnya, pada asma bronkial dapat terjadi juga reaksi fase lambat yang terjadi dalam 2-24 jam kemudian, tanpa ada tambahan eksposure antigen dan dapat bertahan dalam beberapa hari. Fase ini ditandai dengan dengan infiltrasi jaringan oleh eosinofil, netrofil, basofil, monosit, dan sel $\mathrm{T}$ CD4++ serta kerusakan jaringan yang seringkali bermanifestasi sebagai kerusakan epitel mukosa (Subowo, 2010).

Reaksi IgE (anafilaktik) ini memiliki tiga tahapan utama berupa fase sensitisasi, fase aktivasi dan fase efektor. Fase sensitisasi merupakan waktu yang dwanitatuhkan untuk membentuk IgE sampai diikat silang oleh reseptor spesifik (Fce-R) pada permukaan. Fase aktivasi merupakan waktu yang diperlukan antara pajanan ulang dengan antigen spesifik dan sel mast/basofil melepas isinya yang berisikan granul yang nantinya akan menimbulkan reaksi alergi. Hal tersebut terjadi oleh ikatan silang antara antigen dan IgE. Fase efektor yaitu waktu terjadi respons yang kompleks (anafilaksis) sebagai efek mediator-mediator yang dilepas oleh sel mast/basofil dengan aktivitas farmakologik (Subowo, 2010).

\section{Pengaruh Kehamilan Pada Asma}

Perubahan hormonal yang terjadi selama kehamilan mempengaruhi hidung, sinus dan paru. Peningkatan hormon estrogen menyebabkan kongesti kapiler hidung, terutama selama trimester ketiga, sedangkan peningkatan kadar hormon progesteron menyebabkan peningkatan laju pernapasan (ACAAI, 2002).

Pengaruh kehamilan terhadap timbulnya serangan asma pada setiap penderita tidak sama, bahkan pada seorang penderita asma serangannya tidak sama pada kehamilan pertama dan kehamilan berikutnya. Biasanya serangan akan timbul mulai usia kehamilan 24 minggu sampai 36 minggu, dan akan berkurang pada akhir kehamilan. Pengaruh asma pada wanita dan janin sangat bergantung dari frekuensi dan beratnya serangan asma, karena wanita dan janin akan mengalami hipoksia. Keadaan hipoksia jika tidak segera diatasi tentu akan memberikan pengaruh buruk pada janin, berupa abortus, persalinan prematur, dan berat janin yang tidak sesuai dengan umur kehamilan (Subijanto, 2008).

Efek kehamilan pada asma tidak dapat diprediksi. Turner et al dalam suatu penelitian yang melibatkan 1054 wanita hamil yang menderita asma menemukan 
bahwa 29\% kasus membaik dengan terjadinya kehamilan, $49 \%$ kasus tetap seperti sebelum terjadinya kehamilan, dan $22 \%$ kasus memburuk dengan bertambahnya umur kehamilan. Sekitar $60 \%$ wanita hamil yang mendapat serangan asma dapat menyelesaikan kehamilannya dengan baik. Sekitar 10\% akan mengalami eksaserbasi (serangan asma dengan episode meningkat) pada persalinan, bahkan peningkatan 18 kali lipat resiko eksaserbasi pada persalinan dengan seksio sesarea dibandingkan dengan pervaginam (Subijanto, 2008).

\section{Pengaruh Asma Pada Kehamilan}

Asma pada kehamilan pada umumnya tidak mempengaruhi janin, namun serangan asma berat dan asma yang tak terkontrol dapat menyebabkan hipoksemia wanita sehingga berefek pada janin (Nelson and Piercy, 2001). Hipoksia janin terjadi sebelum hipoksia wanita terjadi. Asma pada kehamilan berdampak penting bagi wanita dan janin selama kehamilan dan persalinan. Dampak yang terjadi dapat berupa kelahiran prematur, usia kehamilan muda, hipertensi pada kehamilan, abrupsio plasenta, dan seksio sesaria (Liu et al, 2000 ; Bathia and Bathia, 2000).

\section{Kesimpulan}

Perubahan fisiologis selama kehamilan dapat mengubah prognosis asma karena adanya perubahan hormonal selama kehamilan. Bronkodilatasi yang dimediasi oleh progesteron serta peningkatan kadar kortisol serum bebas merupakan salah satu perubahan fisiologis kehamilan yang dapat memperbaiki gejala asma, sedangkan prostaglandin F2 dapat memperburuk gejala asma karena efek bronkokonstriksi yang ditimbulkannya.

Allergen yang masuk ke dalam tubuh akan menimbulkan respon imun berupa produksi $\operatorname{IgE}$ dan penyakit alergi seperti asma, rhinitis alergi, dan dermatitis atopi. Reaksi IgE timbul segera setelah adanya pajanan dengan allergen. Reaksi ini dapat terjadi dalam hitungan menit setelah terjadi kombinasi antigen dengan antibodi yang terikat pada sel mast pada individu yang telah tersensitisasi terhadap antigen. Paparan terhadap aeroallergen pada wanita saat kehamilan dapat meningkatkan resiko sensitisasi terhadap janin sehingga pajanan alergi yang merangsang produksi $\operatorname{IgE}$ spesifik sudah dapat terjadi sejak bayi dalam kandungan.

Pengaruh kehamilan terhadap timbulnya serangan asma pada setiap penderita tidak sama, bahkan pada seorang penderita asma, serangannya tidak sama pada kehamilan pertama dan kehamilan berikutnya. Biasanya serangan akan timbul mulai usia kehamilan 24 minggu sampai 36 minggu, dan akan berkurang pada akhir kehamilan. Peningkatan kadar IgE diperkirakan akan memperburuk keadaan asma selama kehamilan, sebaliknya penderita dengan kadar IgE yang menurun akan membaik keadaannya selama kehamilan.

\section{Saran}

Masyarakat diharapkan untuk lebih memperhatikan dan mewaspadai setiap keadaan pada penderita asma khususnya bagi para wanita hamil untuk meminimalisir terjadinya pengaruh buruk pada janin yang dapat menyebabkan abortus, persalinan prematur, dan berat janin yang tidak sesuai dengan umur kehamilan.

\section{Daftar Pustaka}

Abbas AK, Lichtman AH Pilai S., (2010). Cellular and Molecular Immunology, $6^{\text {th }} E d$. Philadelphia : Saunders Elsevier.

ACAAI, (2002). When Pregnancy is Complicated by Allergies and Asthma. Illionis, IL: Pregnancy Committee of the American College of Allergy Asthma and Immunology.

Arulita, Ika Fibriana, (2007). Jurnal Penelitian : Faktor- Faktor Risiko yang Mempengaruhi Kematian Maternal (Studi Kasus di Kabupaten Cilacap). Semarang : Program Studi Epidemiologi Program Pasca Sarjana Undip Semarang. 
Baratawidjaja KG, Rengganis I., (2010). Imunologi Dasar, Ed $9^{\text {th }}$. Jakarta : Balai Penerbit FKUI.

Bhatia P, Bhatia K., (2000). Pregnancy and the lung. Postgrad Med J 76: 638-639.

Dedi, A., (2010). Majalah Kedokteran Nusantara Vol 41 No 4 Desember 2008 - Eosinofil dan Patogenesa Asma. Sumatera Utara : Departemen Fisiologi Fakultas Kedokteran Universitas Sumatera Utara.

Eddy, S., Juli, P., (2009). Jurnal Penelitian : Mekanisme Seluler dalam Patogenesis Asma dan Rinitis. Surakarta : Departemen Pulmonologi dan Ilmu Kedokteran Respirasi FK UNS/ SMF Paru RSUD Dr. Moewardi Surakarta.

Frieri, Marianne, (2004). Management of Asthma in Women Vol 7 No 8. Women's Health In Primary Care.

Gabbe, S. et al. (2007). Obstetrics Normal and Problem Pregnancies Ed 5. Philadelphia : Churcill Livingstone.

Hertantiyo, B., (2013). Jurnal Penelitian : Asma Dalam Kehamilan. Lampung : Unila.

Kumar, Abbas, Fausto, Aster. Robbns and Cotran., (2010). Disease of The Immune System, $8^{\text {th }} \mathrm{Ed}$. Philadelphia : Saunders Elsevier.

Lie, T Merijanti S., (2011). Jurnal Kedokteran September-Desember 1999 Vol 18 No 3 : Peran Sel Mast Dalam Reaksi Hipersensitivitas Tipe-I. Bagian Histologi Fakultas Kedokteran Universitas Trisakti.

Liu S, Wen SW, Demissie K, Marcoux S, Kramer MS., (2000). Maternal Asthma and Pregnancy Outcomes : A retrospective cohort study. Am J Obstet Gynecol 184 (2): 383-342.

Mai, L.D.R., (2013). Jurnal Penelitian Vol 2 No 1 : Pengaruh Karakteristik, Perilaku, dan Sosial Ekonomi Wanita Terhadap Kelahiran Bayi BBLR (Berat Bayi Lahir Rendah) di Kabupaten Sidoarjo. Surabaya : UNESA.
Nelson C, Piercy., (2001). Asthma in Pregnancy. in : Respiratory diseases in pregnancy-1. Thorax 56:325-328.

Nugroho, Taufan, (2010). Buku Ajar Obstetri Untuk Mahasiswa Kebidanan Cet.1, Yogyakarta : Nuha Medika.

Oxorn, Harry, \& Forte, William R., (2010). Ilmu Kebidanan : Patologi Dan Fisiologi Persalinan (Human Labor \& Birth) Ed.1, Yogyakarta : CV. ANDI OFFSET \& Yayasan Essentia Medica (YEM).

Purnomo, (2008). Jurnal Penelitian : Faktorfaktor Risiko Yang Berpengaruh Terhadap Kejadian Asma Bronkial Pada Anak (Studi Kasus di RS Kabupaten Kudus). Semarang : Program Studi Magister Epidemiologi Program Pasca Sarjana Undip Semarang.

Reece Albert E, et al., (2007). Clinical Obstetric the Fetus and Mother, $3^{\text {rd }}$ edition. Massachusets, Blackwel Publishing.

Rengganis, Iris, (2008). Jurnal Penelitian Volume 58 Nomor 11 Nopember 2008 : Diagnosis dan Tatalaksana Asma Bronkial. Jakarta : Departemen Ilmu Penyakit Dalam FKUI, RSCM.

Rosenstreich, David L et al., (2003). Journal Of Asthma Vol 40 : Asthma and The Environment. Editor David G. Tinkelman, M. D etc.

Sofian, Amru, (2011). Rustam Mochtar Sinopsis Obstetri : Obstetri Fisiologi, Obstetri Patologi Ed.3, Jilid 1, Jakarta : EGC.

Sony, P.L, Qomariyah, Endang, P., (2011). Artikel Penelitian Vol 3 No 2 : Persentase Distrwanitasi Penyakit Genetik dan Penyakit Yang Dapat Disebabkan Oleh Faktor Genetik Di RSUD Serang. Universitas YARSI : Majalah Kesehatan PharmaMedika.

Subijanto, Achmad Arman, (2008). Jurnal Penelitian Biodiversitas Vol 8 No 3 Juli 2008 : Keanekaragaman Genetik HLADR dan Variasi Kerentanan terhadap Penyakit Asma; Tinjauan Khusus pada 
Asma dalam Kehamilan. Surakarta : Fakultas Kedokteran Universitas Sebelas Maret Surakarta.

Subowo, (2010). Imunologi Klinik : Hipersensitivitas, $E d 2^{\text {nd }}$. Jakarta : Sagung Seto.

Sundaru H, Sukamto, (2006). Asma Bronkial. Jakarta : Departemen Ilmu Penyakit Dalam Fakultas Kedokteran Universitas Indonesia.

Widjaya, Indriani, (2010). Buku Pintar Atasi Asma. Yogyakarta : Pinang Merah.

Widura, (2002). Jurnal Kedokteran Maranatha Vol 1 No 2 : Patogenesis Asthma Bronchiale. Bagian Mikrobiologi Fakultas Kedokteran Universitas Kristen Maranatha.

Winkjosastro, H., Saifuddin, A.B., \& Rachimhadhi, T., (2014). Ilmu Kebidanan Edisi Keempat Cet.8, Jakarta : Yayasan Bina Pustaka Sarwono Prawirohardjo.

Wray, Betty B. and Mc Cann, William. (2003). Journal Of Asthma Vol 40 : Bronchial Asthma. Editor David G. Tinkelman, M. D etc. 